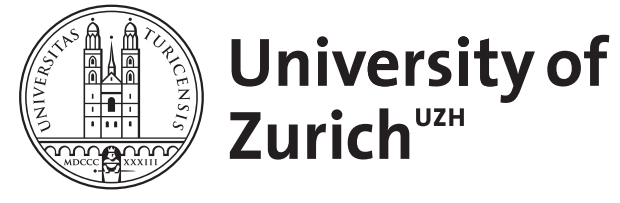

Zurich Open Repository and Archive

University of Zurich

University Library

Strickhofstrasse 39

CH-8057 Zurich

www.zora.uzh.ch

Year: 1999

\title{
A visit to Professor Mirko Tos, Gentofte University Hospital, Copenhagen
}

Nandapalan, V

DOI: https://doi.org/10.1017/s0022215100144585

Posted at the Zurich Open Repository and Archive, University of Zurich

ZORA URL: https://doi.org/10.5167/uzh-155302

Journal Article

Published Version

Originally published at:

Nandapalan, V (1999). A visit to Professor Mirko Tos, Gentofte University Hospital, Copenhagen. Journal of Laryngology and Otology, 113(6):593-594.

DOI: https://doi.org/10.1017/s0022215100144585 


\section{The JLO Travelling Fellowship}

\section{A visit to Professor Mirko Tos, Gentofte University Hospital, Copenhagen}

\author{
V. NANDAPalan, F.R.C.S. (ORL) \\ Clinical and Research Fellow to Professor Ugo Fisch, \\ University Hospital, Zurich.
}

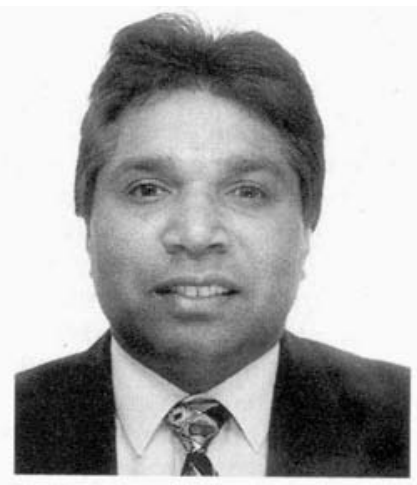

In Copenhagen virtually all stapes surgery is undertaken under local anaesthesia via the permeatal approach.

Professor Tos operates on almost all patients with cholesteatoma. In case of a small cholesteatoma, he recommends permeatal atticotomy leaving a thinned bridge of outer attic wall, which is very useful when planning the single stage reconstruction. If the cholesteatoma is extensive he prefers a post auricular approach and tries to avoid an open cavity. He never routinely performs 2nd look operations, believing that a thorough removal in his hands rarely leads to recurrence.

I was impressed that Professor Tos still practices on temporal bones as do his senior colleagues. This is an important lesson for all of us.

Every afternoon, a meeting is held in the ENT department, where all the medical staff including Professor Tos, nursing staff from the ward and theatres attend. The doctor responsible for the ward that day presents each case and the patient's management is discussed. This is particularly useful as everyone gets involved in the management of all patients. There is a twice weekly meeting with the radiologists and a monthly meeting with pathologists. Professor Tos has an excellent collection of teaching videos that are available for visiting doctors to see. There is also an opportunity to get involved in a research project which consisted in a modification of the classification of isolated congenital stapes ankylosis and a detailed embryological review to explain the pathogenesis of the ankylosis.

A visit to Copenhagen cannot fail to impress the visitor. The Gentofte University Hospital has an attractive campus, welcoming people and is close to the city of Copenhagen to the south and the beaches to the north.

During my stay in Cophenhagen, I had the opportunity to visit Professor Paul Bretlau's ENT department at Riggs Hospital. He has a major Head and Neck Surgery unit and a well equipped vestibular function test centre. I was able to observe a number of head and neck surgical procedures and Professor Bretlau performing stapes surgery using Erbium YAG laser. I also had the opportunity to visit Dr. Per Bonding's ENT department at Glosstrup Hospital in Copenhagen and Professor Mans Magnuson's excellent vestibular function assessment and rehabilitation centre at the Lund University Hospital, Sweden. 
This trip has been an invaluable learning experience and I have been taught many new techniques and procedures both as an observer and as assistant. With the Calman training programme, registrars are so 'regionalized'. It is a great pleasure therefore to have the opportunity to learn new skills and meet the great masters in this field.

I wish to thank:

1. Professor Tos and his staff for giving me the opportunity to visit their department, and creating a very friendly environment to work.

2. The JLO for providing the major funding to make this trip possible.

3. Professor Paul Bretlau, Mans Magnuson and Dr. Per Bonding for giving me the opportunity to visit their respective departments.

4. To the Consultant ENT surgeons at University Hospital, Aintree and the Post Graduate Dean at Mersey Deanery who enthusiastically not only supported me to take the time off but also allowing part of the period as a study leave.

5. Royal Society of Medicine and Ethicon for their awards to fund this trip, so that I was not out of pocket.

6. Last but not least, to my wife Susie, who made sure we kept our expenses well within the budget in an expensive country, and for looking after our baby Kavitha while I was working quite late to finish the projects. 